\title{
PEMBELAJARAN TREFFINGER BERBANTUAN PERMAINAN TRADISIONAL CONGKLAK UNTUK MENINGKATKAN KEMAMPUAN KOMUNIKASI MATEMATIS
}

\author{
Himmatul Ulya ${ }^{1)}$, Ratri Rahayu ${ }^{2)}$ \\ ${ }^{1,2)}$ Fakultas Keguruan dan Ilmu Pendidikan, Universitas Muria Kudus \\ Email: ${ }^{1)}$ himmatul.ulya@umk.ac.id, ${ }^{2)}$ ratri.rahayu@umk.ac.id
}

\begin{abstract}
The goals of this study were: (1) to determine whether the mathematical communication ability of students through the application of treffinger learning using a traditional game of congklak on multiplication material reach the completeness learning and (2) to determine the quality improvement of students' mathematical communication ability who joined treffinger learning using a traditional game of congklak on multiplication material. This study was an experimental research with one-group pretest-posttest design. The research implemented on $2^{\text {nd }}$ grade ini SD 1 Bae Kudus in multiplication material. The techniques of data collection used was test to measure mathematical communication ability of students. The techniques of data analysis in the study included the analysis of data to determine the completeness learning and to analyze the improvement students' mathematical communication ability. The results of study showed that through the application of treffinger learning using a traditional game of congklak, then (1) mathematical communication ability of students reach the completeness learning, either individually and classical and (2) students' mathematical communication ability had increased in the medium category by $65 \%$.
\end{abstract}

Keywords: congklak, mathematical communication ability, treffinger

\section{PENDAHULUAN}

Salah satu faktor penentu keberhasilan pembangunan untuk meningkatkan kualitas sumber daya manusia yaitu dengan pendidikan yang bermutu. Namun realita di lapangan menunjukkan bahwa kualitas manusia Indonesia sebagai sumber daya yang potensial masih jauh dari harapan. Menurut Widodo (2015), hal ini terjadi akibat rendahnya kualitas pendidikan di Indonesia. Perbaikan kualitas pendidikan di Indonesia saat ini perlu diupayakan oleh pemerintah, masyarakat, orang tua, dan guru.

Kualitas pendidikan dapat diperbaiki dengan berbagai cara. Salah satu langkah untuk memperbaiki kualitas pendidikan yaitu melalui pembelajaran. National Council of
Teachers of Mathematics (NCTM) menyatakan bahwa pembelajaran matematika seharusnya membuat peserta didik memahami hal yang dipelajari dan mampu belajar dengan baik (NCTM, 2000). Hal ini berarti peserta didik dapat mempelajari matematika secara bermakna dan dapat menggunakan matematika di dalam aplikasi kehidupan sehari-hari.

Kenyataan di lapangan, pembelajaran matematika masih berpusat pada guru sehingga peserta didik belum diberi kesempatan untuk aktif mengembangkan kemampuannya dan terbuka menyampaikan gagasannya dalam matematika. Akibatnya, kemampuan komunikasi matematis peserta didik menjadi rendah. Fakta tersebut senada dengan pendapat 
Siswono (2012), yaitu selama ini pembelajaran matematika masih didominasi oleh pengenalan rumusrumus serta konsep secara verbal tanpa memperhatikan pemahaman peserta didik terhadap konsep yang sedang dipelajari. Hal ini bertentangan dengan NCTM (2000) yang menyatakan bahwa hal yang paling mendasar dalam pembelajaran matematika adalah kemampuan komunikasi. Kemampuan komunikasi matematis sangat penting bagi peserta didik, karena tanpa kemampuan komunikasi matematis yang memadai, peserta didik akan kesulitan untuk menyampaikan gagasan dan ide yang ada dalam pikirannnya.

Pentingnya kemampuan

komunikasi matematis juga dinyatakan oleh Lange (2004), yaitu berkomunikasi secara matematis (mathematical communication) merupakan kompetensi yang harus dipelajari dan dikuasai peserta didik selama pembelajaran matematika. Peserta didik harus mampu menyatakan pendapat dan ide secara lisan, tulisan, maupun bentuk lain serta mampu memahami pendapat dan ide orang lain. Hal ini berarti bahwa komunikasi matematis merupakan cara berbagi ide dan memperjelas pemahaman tentang matematika.

Laporan hasil Trends in

International Mathematics and Science Study (TIMSS) tahun 2015 menyatakan bahwa rata-rata skor matematika peserta didik di Indonesia berada di bawah rata-rata skor internasional. Indonesia hanya memperoleh skor 397 dari skor rata-rata internasional adalah 500 (Mullis, et al., 2015). Hasil tersebut menunjukkan bahwa pendidikan matematika di Indonesia selama ini belum mengarahkan peserta didik untuk berpikir tingkat tinggi dan tidak dapat memberikan kesempatan peserta didik mengkomunikasikan pendapat, ide, dan gagasannya.
SD 1 Bae Kudus merupakan salah satu sekolah dasar di Kabupaten Kudus. Berdasarkan hasil observasi dan wawancara dengan guru kelas II, diperoleh informasi bahwa pembelajaran matematika di SD tersebut belum menggunakan pendekatan dan metode pembelajaran yang bervariasi sehingga menyebabkan peserta didik merasa bosan dan cenderung lebih menyukai bermain dengan temannya. Selain itu, kemampuan komunikasi matematis peserta didik masih tergolong rendah. Hal ini dibuktikan dengan peserta didik kesulitan ketika diminta untuk memberikan pendapat atau tanggapan mengenai konsep yang dipelajari. Beberapa peserta didik juga mengalami kesulitan dalam menginterpretasikan suatu permasalahan ke dalam sketsa gambar atau bahasa matematika yang sederhana.

Berdasarkan hasil penelitian sebelumnya dari Riyono, et al. (2016) menyimpulkan bahwa kemampuan komunikasi matematis dapat ditingkatkan dengan cara pembelajaran mind mapping, yang merupakan salah satu jenis dari pembelajaran kooperatif disertai dengan penilaian produk. Pembelajaran tersebut mengarahkan peserta didik untuk mengkomunikasikan ide matematikanya dan membimbing peserta didik untuk belajar penemuan.

Berdasarkan permasalahan dan penelitian yang telah dilakukan sebelumnya, maka diperlukan pembelajaran inovatif dan menyenangkan dalam pembelajaran matematika untuk meningkatkan kemampuan komunikasi matematis. Pembelajaran yang dilakukan akan disesuaikan dengan kondisi peserta didik yang masih senang bermain, yaitu dengan mengintegrasikan permainan tradisional congklak di dalam 
pembelajaran tersebut.

Salah satu alternatif untuk pembelajaran inovatif adalah pembelajaran kooperatif. Pembelajaran kooperatif tipe treffinger akan melatih peserta didik untuk mengungkapkan gagasannya karena di dalam tahapannya terdapat sintaks generating idea. Hal ini bertujuan agar peserta didik terbiasa untuk menyampaikan ide dan pendapatnya di dalam pembelajaran matematika sehingga dapat meningkatkan kemampuan komunikasi matematis peserta didik. Selain itu, permainan akan dimasukkan ke dalam pembelajaran agar peserta didik merasa senang dalam belajar matematika. Permainan yang digunakan merupakan permainan tradisional congklak agar peserta didik tertarik dalam belajar secara kontekstual dan juga mengenal budaya permainan tradisional di daerahnya. Dengan pembelajaran yang menyenangkan, kemampuan komunikasi matematis akan meningkat sehingga akan berpengaruh pada hasil belajar yang optimal.

Berdasarkan uraian di atas, maka perlu dilakukan penelitian untuk meningkatkan kemampuan komunikasi matematis melalui penerapan pembelajaran treffinger berbantuan permainan tradisional congklak dalam pembelajaran matematika materi perkalian pada peserta didik kelas II semester 2 SD 1 Bae Kudus tahun pelajaran 2016/2017. Tujuan dalam penelitian ini yaitu: (1) mengetahui apakah kemampuan komunikasi matematis peserta didik dengan penerapan model pembelajaran treffinger berbantuan permainan tradisional congklak pada materi perkalian mencapai ketuntasan belajar dan (2) mengetahui kualitas peningkatan kemampuan komunikasi matematis peserta didik yang mengikuti pembelajaran treffinger berbantuan permainan tradisional congklak pada materi perkalian.

\section{METODE PENELITIAN}

Jenis penelitian yang digunakan adalah penelitian eksperimen dengan metode pre-experimental design. Metode tersebut digunakan karena di dalam penelitian ini tidak ada variabel kontrol dan tidak dipilih secara random. Desain penelitian dalam penelitian ini mengacu pada one-group pretestposttest design. Tabel rancangan dalam penelitian ini disajikan pada Tabel 1 berikut.

Tabel 1 Desain Penelitian

\begin{tabular}{|c|c|c|c|}
\hline Kelompok & Pretest & Perlakuan & Posttest \\
\hline Eksperimen & $O_{1}$ & $\mathrm{X}$ & $O_{2}$ \\
\hline
\end{tabular}

(Sugiyono, 2010)

Keterangan :

$O_{1}:$ Tes awal (Pretest)

$\mathrm{X}$ : Penerapan pembelajaran treffinger berbantuan permainan tradisional congklak

$\mathrm{O}_{2}:$ Tes akhir (Posttest)

Pada desain ini, subjek penelitian tidak dipilih secara random karena penelitian yang dilakukan disesuaikan dengan situasi dan kondisi di lapangan. Sebelum diberi perlakuan, peserta didik diberi pretest untuk mengukur kemampuan komunikasi matematisnya. Selanjutnya peserta didik diberi perlakukan dengan menerapkan pembelajaran treffinger berbantuan permainan tradisional congklak dalam materi perkalian. Setelah perlakukan diterapkan, peserta didik diberikan posttest 
untuk mengukur kemampuan komunikasi matematis. Soal pretest dan posttest yang digunakan untuk mengumpulkan data peserta didik memiliki tingkatan yang sama.

Teknik pengumpulan data dalam penelitian ini menggunakan teknik tes. Teknik tes digunakan untuk memperoleh data kemampuan komunikasi matematis peserta didik sebelum dan sesudah pembelajaran.

Teknik analisis data dalam penelitian ini meliputi analisis data untuk menentukan ketuntasan belajar dan menganalisis peningkatan kemampuan komunikasi matematis peserta didik. Uji ketuntasan belajar digunakan untuk menguji ketercapaian ketuntasan kemampuan komunikasi matematis peserta didik dengan penerapan model pembelajaran treffinger berbantuan permainan tradisional congklak pada materi perkalian. Indikator mencapai ketuntasan belajar yaitu mencapai ketuntasan individual dan ketuntasan klasikal. Ketuntasan individual dapat ditentukan melalui uji $\mathrm{t}$ satu pihak. Ketuntasan klasikal merupakan persentase peserta didik yang mencapai ketuntasan individu minimal $75 \%$ dari banyaknya peserta didik. Uji ketuntasan belajar secara klasikal diuji menggunakan uji proporsi satu pihak.

\section{HASIL PENELITIAN DAN PEMBAHASAN}

Data kemampuan komunikasi matematis peserta didik diperoleh dari pengukuran menggunakan instrumen tes kemampuan komunikasi matematis. Instrumen tes tersebut terdiri dari 7 butir soal uraian. Tes dilakukan sebelum (pretest) dan sesudah (posttest) pemberian perlakuan pembelajaran treffinger berbantuan media permainan congklak. Analisis data kemampuan komunikasi matematis peserta didik meliputi uji normalitas, uji ketuntasan belajar, dan uji peningkatan menggunakan uji normalized gain.

\section{Analisis Deskriptif Data Kemampuan Komunikasi Matematis}

Analisis deskriptif dari data kemampuan komunikasi matematis sebelum dan sesudah perlakuan penerapan pembelajaran treffinger berbantuan media permainan congklak disajikan pada Tabel 2 berikut.

Tabel 2 Deskripsi Data Kemampuan Komunikasi Matematis

\begin{tabular}{|c|l|c|c|}
\hline No & \multicolumn{1}{|c|}{ Analisis Deskriptif } & Sebelum Perlakuan & Sesudah Perlakuan \\
\hline 1 & Banyaknya Peserta Didik & 41 & 41 \\
\hline 2 & Skor Maksimal & 100 & 100 \\
\hline 3 & Nilai Tertinggi & 86 & 100 \\
\hline 4 & Nilai Terendah & 15 & 45 \\
\hline 5 & Rata-rata & 46,61 & 81,46 \\
\hline 6 & Varians & 214,98 & 169,48 \\
\hline 7 & Simpangan Baku & 14,66 & 13,02 \\
\hline 8 & Ketuntasan belajar & $2,44 \%$ & $87,80 \%$ \\
\hline
\end{tabular}

Tabel 2 menunjukkan bahwa kemampuan komunikasi matematis peserta didik sesudah perlakuan lebih baik daripada sebelum pemberian perlakuan pembelajaran treffinger berbantuan media permainan congklak. Hal ini ditunjukkan dari nilai rata-rata kemampuan komunikasi matematis sebelum perlakuan yaitu 46,61, sedangkan rata-rata sesudah perlakuan yaitu 81,46. Pada saat sebelum diberi perlakuan hanya $2,44 \%$ peserta didik yang mencapai ketuntasan belajar, sedangkan setelah perlakuan diberikan peserta didik yang mencapai ketuntasan belajar sebanyak 87,80\%.

\section{Uji Ketuntasan Belajar}

Uji ketuntasan belajar dilakukan untuk menguji apakah kemampuan 
komunikasi matematis peserta didik pada materi perkalian dengan penerapan pembelajaran treffinger berbantuan media permainan congklak dapat mencapai ketuntasan belajar. Indikator mencapai ketuntasan belajar yaitu mencapai ketuntasan individual dan ketuntasan klasikal. Ketuntasan belajar didasarkan pada Kriteria Ketuntasan Minimal (KKM) yaitu 70 untuk ketuntasan individual sedangkan ketuntasan klasikal yaitu $75 \%$.

Sebelum dilakukan uji ketuntasan belajar, terlebih dahulu data posttest diuji normalitasnya. Hal ini dilakukan sebagai uji prasyarat untuk menguji hipotesis ketuntasan belajar. Analisis normalitas dalam penelitian ini menggunakan Kolmogorov-Smirnov dengan bantuan program SPSS 16. Hipotesis yang diajukan yaitu $H_{0}$ yaitu data berasal dari populasi yang berdistribusi normal atau $H_{1}$ yaitu data berasal dari populasi yang tidak berdistribusi normal. Kriteria $H_{0}$ diterima jika nilai signifikansi KolmogorovSmirnov pada kolom Asymp. Sig (2-tailed) lebih dari 0,05. Hasil analisis menggunakan SPSS menunjukkan bahwa nilai signifikansi pada kolom Asymp. Sig (2-tailed) adalah 0,130 yang berarti lebih dari taraf nyata 0,05 . Oleh karena $0,130>$ 0,05 maka disimpulkan bahwa data berasal dari populasi yang berdistribusi normal.

Uji ketuntasan belajar secara individual menggunakan uji $\mathrm{t}$ satu pihak. Hipotesis yang diajukan adalah $H_{0}: \mu \leq$ 70 sedangkan untuk $H_{1}: \mu>70$. Kriteria pengujian yang digunakan yaitu tolak $H_{0}$ jika $t_{\text {hitung }} \geq t_{\text {tabel }}$. Nilai $t_{\text {tabel }}$ diperoleh dari daftar tabel distribusi $\mathrm{t}$ dengan $d k=n-1=41-1=40$ dan $\alpha=5 \%$, sehingga nilai $t_{\text {tabel }}$ yang digunakan adalah 1,6839. Dari hasil perhitungan diperoleh bahwa $t_{\text {hitung }}=5,64$. Oleh karena $t_{\text {hitung }} \geq t_{\text {tabel }}$ maka $H_{0}$ ditolak, artinya kemampuan komunikasi matematis peserta didik yang diajar dengan pembelajaran treffinger berbantuan media permainan congklak telah mencapai KKM.

Uji ketuntasan belajar secara klasikal dapat dianalisis menggunakan uji proporsi satu pihak. Hipotesis yang diajukan yaitu $H_{0}: \pi \leq 0,75$ dan $H_{1}: \pi>0,75$. Kriteria pengujian yaitu $\mathrm{H}_{0}$ ditolak jika $z_{\text {hitung }} \geq$ $z_{\text {tabel }}$. Nilai $z_{\text {tabel }}$ merupakan $z_{0,5-\alpha}$ dengan $\alpha=5 \%$. Nilai tersebut dapat diperoleh dari daftar tabel distribusi $\mathrm{z}$. Nilai $z_{0,45}$ dengan $\alpha=5 \%$ adalah 1,64 . Berdasarkan hasil perhitungan diperoleh bahwa $z_{\text {hitung }}=1,89$. Nilai $z_{\text {hitung }}=$ $1,89 \geq z_{0,45}=1,64$ sehingga $H_{0}$ ditolak. Hal ini berarti kemampuan komunikasi matematis peserta didik yang dikenai pembelajaran treffinger berbantuan media permainan congklak telah mencapai ketuntasan belajar secara klasikal.

\section{Uji Normalized Gain Data Kemampuan Komunikasi Matematis}

Data kemampuan komunikasi matematis peserta didik selanjutnya dianalisis dengan menggunakan uji normalized gain untuk mengetahui peningkatan kemampuan komunikasi matematis peserta didik sebelum dan sesudah pembelajaran. Di dalam penelitian ini, peningkatan dihitung melalui rumus gain yaitu meghitung selisih antara skor posttest dan skor pretest kemudian dibagi dengan selisih antara skor maksimum dan skor pretest. Rekapitulasi peningkatan kemampuan komunikasi matematis peserta didik secara individual dengan menggunakan uji normalized gain ditunjukkan pada Tabel 3, sedangkan peningkatan kemampuan komunikasi matematis peserta didik secara klasikal ditunjukkan pada Tabel 4.

Tabel 3 Rekapitulasi Peningkatan Kemampuan Komunikasi Matematis Individual

\begin{tabular}{|c|c|c|}
\hline Kriteria & Banyaknya Peserta Didik & Persentase \\
\hline Rendah & 4 & $9,76 \%$ \\
\hline
\end{tabular}


ISSN 2089-8703 (Print) Vol. 6, No. 1 (2017)

ISSN 2442-5419 (Online)

\begin{tabular}{|c|c|c|}
\hline Sedang & 16 & $39,02 \%$ \\
\hline Tinggi & 21 & $51,22 \%$ \\
\hline
\end{tabular}

Berdasarkan Tabel 3 dapat diperoleh informasi bahwa sebanyak 51,22\% atau 21 peserta didik mengalami peningkatan kemampuan komunikasi matematis yang tinggi, sebesar $39,02 \%$ atau 16 peserta

didik mengalami peningkatan pada kategori sedang, dan $9,76 \%$ atau 4 peserta didik mengalami peningkatan pada tingkat rendah.

Tabel 4 Rekapitulasi Peningkatan Kemampuan Komunikasi Matematis Klasikal

\begin{tabular}{|c|c|c|}
\hline Rata-Rata Pretest & Rata-Rata Posttest & $\langle\boldsymbol{g}\rangle$ \\
\hline 46,61 & 81,46 & 0,65 \\
\hline
\end{tabular}

Tabel 4 menunjukkan bahwa peningkatan kemampuan komunikasi matematis peserta didik secara klasikal yaitu sebesar 0,65 atau $65 \%$. Hal ini berarti bahwa rata-rata peningkatan kemampuan komunikasi matematis peserta didik secara klasikal termasuk dalam kategori sedang.

Berdasarkan analisis deskriptif data kemampuan komunikasi matematis sebelum dan sesudah pemberian perlakuan pembelajaran treffinger berbantuan media permainan congklak diperoleh data bahwa rata-rata kemampuan komunikasi matematis sesudah diberi perlakuan lebih tinggi daripada sebelum diberikan penerapan pembelajaran treffinger berbantuan media permainan congklak. Kemampuan komunikasi matematis peserta didik menjadi lebih baik karena melalui pembelajaran treffinger berbantuan media permainan congklak peserta didik dibimbing untuk memecahkan masalah dan mengkomunikasikan ide-ide matematikanya. Hal ini sesuai dengan Putra dan Sari (2015) yang menyatakan bahwa melalui pembelajaran treffinger peserta didik diajarkan untuk berpikir tingkat tinggi sehingga mampu memunculkan dan mengembangkan gagasan matematisnya.

Hasil uji ketuntasan belajar dari data kemampuan komunikasi matematis menunjukkan bahwa setelah peserta didik diberi perlakuan pembelajaran treffinger berbantuan media permainan congklak mencapai ketuntasan belajar. Ketuntasan belajar tersebut didasarkan pada KKM yang ditetapkan di SD 1 Bae Kudus. KKM individual yang ditetapkan untuk mata pelajaran matematika yaitu 70 sedangkan ketuntasan klasikal yaitu berdasarkan persentase peserta didik yang mencapai ketuntasan individual minimal sebesar $75 \%$. Hasil ini sesuai dengan penelitian Rizky dan Kurniasih (2016) yang menunjukkan bahwa penerapan model treffinger dapat meningkatkan ketuntasan belajar peserta didik yang awalnya hanya $33,33 \%$ pada siklus I meningkat menjadi $77,78 \%$ pada siklus II. Hasil tersebut mengindikasikan bahwa pembelajaran treffinger dapat membantu peserta didik dalam mencapai ketuntasan belajarnya.

Berdasarkan data nilai kemampuan komunikasi matematis peserta didik sebelum dan sesudah pembelajaran treffinger berbantuan media permainan congklak, diketahui bahwa terjadi peningkatan kemampuan komunikasi matematis sebesar $65 \%$. Hal ini terjadi karena peserta didik lebih terbiasa dan berani mengungkapkan ide dan gagasannya dalam menyelesaikan permasalahan matematika. Hasil ini diperkuat oleh Nisa (2011) yang menyatakan bahwa di dalam setting pembelajaran treffinger, peserta didik dibimbing untuk menyampaikan gagasan atau ide matematikanya dan menuangkannya dalam tulisan.

Pembelajaran treffinger berbantuan media permainan congklak dapat mengarahkan peserta didik untuk berpikir secara logis tentang hubungan antar konsep matematika dengan permasalahan dalam kehidupan sehari-hari sampai dengan mengkomunikasikannya. Peserta 
didik dibimbing untuk mengkonstruk pengetahuannya sendiri ketika mempelajari materi perkalian. Peserta didik dibimbing menemukan pengetahuan perkalian menggunakan media permainan congklak. Darkasyi, et al. (2014) menyatakan bahwa kemampuan komunikasi matematis peserta didik akan meningkat lebih baik jika peserta didik diberi kesempatan untuk mengkonstruk pengetahuannya sendiri. $\mathrm{Di}$ dalam pembelajaran treffinger berbantuan media permainan congklak, peserta didik juga dilatih untuk menghargai keragaman berpikir dari peserta didik lainnya yang muncul selama proses pembelajaran dan pemecahan masalah. Saling menghargai keragaman berpikir antar peserta didik terjadi ketika interaksi dalam pembelajaran berlangsung.

Peserta didik dengan kelompoknya masing-masing saling berlomba-lomba untuk menyampaikan gagasan dan penyelesaian masalah yang dihadapi. Apabila ada kelompok yang maju untuk mempresentasikan penyelesaiannya, maka kelompok lain mendengarkan kemudian memberikan tanggapan atas penyelesaian masalah dari kelompok yang maju. Hal ini menunjukkan sikap peserta didik terhadap matematika semakin positif. Berdasarkan hasil penelitian Untari (2013) menunjukkan bahwa ada pengaruh positif antara sikap terhadap matematika dengan prestasi belajar peserta didik. Di dalam penelitian ini sikap peserta didik terhadap matematika mengalami peningkatan sehingga kemampuan komunikasi matematis peserta didik juga mengalami peningkatan sebesar $65 \%$.

\section{KESIMPULAN DAN SARAN}

Berdasarkan hasil penelitian dan pembahasan yang telah dilaksanakan, maka dapat diperoleh simpulan bahwa kemampuan komunikasi matematis peserta didik pada pembelajaran treffinger berbantuan permainan tradisional congklak pada materi perkalian mencapai ketuntasan belajar baik secara individual maupun klasikal. Selain itu, kemampuan komunikasi matematis peserta didik mengalami peningkatan. Peningkatan kemampuan komunikasi matematis peserta didik pada kategori rendah sebanyak 4 peserta didik $(9,76 \%)$, kategori sedang sebanyak 16 peserta didik $(39,02 \%)$, dan kategori tinggi sebanyak 21 peserta didik $(51,22 \%)$. Secara klasikal peningkatan kemampuan komunikasi matematis peserta didik sebesar 0,65 atau $65 \%$ yang berarti bahwa rata-rata peningkatan kemampuan komunikasi matematis peserta didik termasuk dalam kategori sedang.

Berdasarkan simpulan yang diperoleh, maka guru dapat menggunakan soal open-ended untuk menggali kemampuan komunikasi matematis peserta didik karena soal open-ended memiliki beragam penyelesaian sehingga setiap peserta didik dapat menyampaikan beragam ide dan gagasan matematikanya. Selain itu, guru hendaknya lebih memperhatikan peserta didik atau kelompok yang mengalami kesulitan dalam menyampaikan ide atau gagasan matematika sehingga peserta didik lebih termotivasi dan mengoptimalkan kemampuan komunikasi matematisnya.

\section{DAFTAR PUSTAKA}

Darkasyi, M. Johar, R., dan Ahmad, A. 2014. Peningkatan Kemampuan Komunikasi Matematis dan Motivasi Siswa dengan Pembelajaran Pendekatan Quantum Learning pada Siswa SMP Negeri 5 Lhokseumawe. Jurnal Didaktik Matematika, Vol. 1 No. 1. Hal 2134.

Lange, J. D. 2004. Mathematical Literacy for Living from OECD-PISA Perspective. Netherland: Utrecht University.

Mullis, I.V.S., et al. (2015). TIMSS 2015 International Results in Mathematics. Chestnut Hill, MA: TIMSS \& PIRLS International Study Center, Boston College. 
NCTM. 2000. Priciples and Standard for School Mathematics. Virgina: NCTM.

Nisa, T.F. 2011. "Pembelajaran Matematika dengan Setting Model Treffinger Untuk Mengembangkan Kreativitas Siswa". Jurnal Pedagogia, Vol. 1 No. 1. Hal 35-50.

Putra, D.F. dan Sari, Y.I. 2015. "Pengaruh Model Pembelajaran Treffinger Terhadap Kemampuan Berpikir Kritis Dan Kreatif Mahasiswa Universitas Kanjuruhan Malang". Jurnal Pendidikan Geografi, Vol. 20 No. 20. Hal 30-38.

Riyono, A., Ulya, H., dan Rahayu, R. Penerapan Model Pembelajaran Mind Mapping dengan Penilaian Produk Untuk Meningkatkan Karakter Tanggung Jawab dan Komunikasi Matematika (Penelitian Dilakukan di SD 1 Peganjaran Kecamatan Bae Kabupaten Kudus).

Laporan Penelitian. Kudus: Universitas Muria Kudus. Tidak Dipublikasikan.

Rizky, E., A. dan Kurniasih, N. 2016. "Peningkatan Kemampuan Komunikasi Matematis dan Pemecahan Masalah Matematika dengan Model Treffinger". Jurnal Ekuivalen, Vol. 20 No. 3. Hal 217222.

Siswono, T.Y.E. 2012. "Implementasi Pendidikan Karakter dalam Pembelajaran Matematika". Prosiding Seminar Nasional Pendidikan Matematika UIN Syarif Hidayatullah Jakarta, Hal 1-12.

Sugiyono. 2010. Metode Penelitian Pendidikan (Pendekatan Kuantitatif, Kualitatif, dan $R \& D)$. Bandung: Alfabeta.

Untari, E. 2013. "Pengaruh Sikap Siswa Terhadap Matematika Pada Prestasi Belajar Siswa SMP di Kabupaten Magetan”. Jurnal Media Prestasi, Vol 12 No. 2. Hal 56-62.

Widodo, H. 2015. "Potret Pendidikan di Indonesia dan Kesiapannya dalam
Menghadapi Masyarakat Ekonomi Asia (MEA)". Jurnal Cendekia, Vol. 13 No. 2. Hal 293-307. 